Transportation Research Forum

Wages and Working Conditions of Truck Drivers at the Ports of Long Beach and Los Angeles Author(s): Kristen Monaco

Source: Journal of the Transportation Research Forum, Vol. 49, No. 1 (Spring 2010), pp. 23-36

Published by: Transportation Research Forum

Stable URL: http://www.trforum.org/journal

The Transportation Research Forum, founded in 1958, is an independent, nonprofit organization of transportation professionals who conduct, use, and benefit from research. Its purpose is to provide an impartial meeting ground for carriers, shippers, government officials, consultants, university researchers, suppliers, and others seeking exchange of information and ideas related to both passenger and freight transportation. More information on the Transportation Research Forum can be found on the Web at www.trforum.org. 


\title{
Wages and Working Conditions of Truck Drivers at the Ports of Long Beach and Los Angeles
}

\author{
by Kristen Monaco
}

Using data from surveys conducted in 2004 and 2006, we examine the work and earnings of drayage drivers at the ports of Los Angeles and Long Beach. Though possessing relatively low levels of education (most have a high school diploma or less), these drivers average approximately \$35,000 in earnings net of truck expenses, working on average 11.2 hours per day. Owner operators experience increased net earnings once their trucks are fully paid for, leading them to buy older, more polluting trucks. This negative externality is currently being addressed by both ports by enacting new regulations regarding truck drayage in Southern California.

\section{INTRODUCTION}

Containerized traffic grew 196\% at the ports of Long Beach and Los Angeles between 1995 and 2007. Accompanying this increased trade volume is increased pressure on terminals, port drayage companies and shippers to increase port throughput while also reducing pollution. One key component of this supply chain is the port drayage driver. At the ports of Los Angeles and Long Beach, which combined were the largest U.S. container port and the fifth largest container port in the world in 2007 (Journal of Commerce, July 28, 2008), the vast majority of these drivers are owner operators (drivers who own their own trucks) who were born outside of the United States. The ports of Los Angeles and Long Beach teamed up to restructure truck drayage in 2007, and their Clean Trucks Program has been used as a resource in developing port drayage programs in other major ports, such as Oakland and New York/New Jersey.

While there is a substantial body of research on truck drivers nationally (for example, Hirsch and Macpherson 1997, Belzer 2000), there is very little known about the subgroup of drivers who work in port drayage. Anecdotal evidence suggests that they possess low levels of education, are often first generation U.S. residents and typically earn less than drivers in other segments of trucking. The purpose of this study is to use data from two surveys of drivers at the ports of Long Beach and Los Angeles to describe this labor force, examining both earnings and work lives.

It is important to understand the nature of the work of these drivers. Though most are owner operators, they do not typically operate with their own authority; rather, they contract with harbor drayage companies. Given that these drayage companies rarely employ drivers, they appear to serve as brokers, linking drivers and loads. Port drayage drivers are dispatched by the firms and proceed to the port and the terminal where the load is to be picked up. The driver waits for his assigned load inside the terminal and is provided with an ocean container on a chassis (a frame with wheels and brakes upon which the container is placed to function as a trailer) that is typically owned or arranged by the ocean carrier. The driver then leaves the port and delivers the load (typically to a destination within 80 miles).

The nature of this work leads to several questions. How many hours do drivers work and how much are they paid? How do the truck expenses of owner operators affect their net "labor" earnings? How much of the driver's time is in non-driving activities (waiting at the terminals)? These questions are important given pending regulations at West Coast ports aimed at reducing the negative externalities involved in port drayage-namely the pollution generated by the older trucks that spend a fair portion of their time idling in terminals waiting to pick up loads. 
These new regulations have spurred significant controversy, as well as pending lawsuits. While the major California ports (the ports of Long Beach, Los Angeles and Oakland) all have designed programs that will require replacement or retrofitting of all trucks to meet 2007 EPA standards by the year 2012, the Port of Los Angeles has also added a requirement that all port truck drivers be employees of trucking companies. Long Beach, adjacent to Los Angeles, has no such employment provision. The Port of Oakland has not yet passed a final plan for port drayage, but its tentative plan calls for the use of employee drivers.

What is most striking in the following analysis is how much of the labor force in the ports of Los Angeles and Long Beach is comprised of owner operators (drivers who own their own trucks). This is in large part due to the changing operating climate of both ocean shipping and trucking in the latter half of the $20^{\text {th }}$ century and will be addressed after a brief description of the data sets.

\section{DESCRIPTION OF THE DATA}

The data for this study come from two surveys of drivers at the ports of Long Beach and Los Angeles. The first, a survey of drivers working at the Port of Long Beach, was conducted in April and May 2004 and the second survey, which looked at drivers at both Long Beach and Los Angeles ports, was conducted in December 2006.

While nationally representative data sets, such as the Current Population Survey, Panel Study of Income Dynamics and National Longitudinal Study of Youth, provide detailed data that is typically used in wage studies across occupations, these data sets do not contain information that would allow researchers to distinguish port drivers from long-haul drivers, or any other subgroup of this occupation. There are some data sets that specifically collect data on truck drivers (for example, the Sloan Trucking Industry Program Driver Survey). However, these typically focus on long-haul and local drivers not involved in port drayage.

The sampling schemes differed across the two time periods, but both had two components. First, container terminals at which to survey drivers were chosen at random. In 2004 three terminals at the Port of Long Beach were selected (only two were used due to logistical problems with the third; there are seven container terminals at the Port). In 2006 four terminals were chosen (two at each port for a combined total of 15).

The second component involved choosing the drivers to participate in the survey. In 2004 surveys were conducted before the gates opened, from 6-7 a m. To ensure our safety once the lines of trucks began moving, the security people at the terminals requested that we leave the premises before the gates opened at 7 a.m. The surveying was conducted during one week in April 2004 and one week in May 2004. The survey days included every weekday. All drivers who were at the wheel of their truck or standing outside their truck were approached and asked to participate in the survey. Drivers who were asleep in their bunk were not approached. The survey instrument was a self-administered questionnaire. Drivers were given a choice of taking the survey in English or Spanish.

In 2006 the survey was administered differently, as extended gate hours were implemented that made it impossible to safely interview truck drivers queued outside of the terminals. Surveys were conducted during lunch-time (11:30 a m.-1:30 p.m.) and dinner-time (4:30-6:30 p m.) on weekdays during a two-week span. During this round of surveys, drivers were offered $\$ 10$ each to participate. The surveys again were self-administered and respondents were given a choice of English or Spanish versions of the survey. The 2004 survey resulted in 175 observations, and the 2006 survey resulted in 197 observations.

While we do not believe that we can consider the data representative of port drivers at the national level, the sampling scheme and participation rate resulted in data representative of drivers who haul containers to and from the terminals at the ports of Los Angeles and Long Beach. The descriptive statistics of the samples are very close to those of Husing et al. (2007), who used our 
results as the baseline against which they assessed their own survey results for their economic analysis of the ports' Clean Trucks Program.

Table 1 presents demographics for the drivers for both 2004 and 2006 data sets (some variables were not present in both data sets). These demographics highlight the commonalities and differences between port drayage drivers and other types of drivers. The drivers are overwhelmingly male and possess low levels of education, as seen in prior research using Current Population Survey data (Belman and Monaco 2001), as well as data on long-haul drivers (Belman, Monaco and Brooks 2005).

Table 1: Driver Demographics

\begin{tabular}{llrr}
\hline & \multicolumn{1}{c}{ Variable } & $\mathbf{2 0 0 4}$ & $\mathbf{2 0 0 6}$ \\
\hline Employment Status & Owner Operator & $80.8 \%$ & $78.5 \%$ \\
& Tenure (in years) & 3.44 & $\mathrm{NA}$ \\
& Experience (in years) & 9.00 & 8.71 \\
Age and gender & Age & & \\
& Male & 41.09 & $38.88 *$ \\
Marital Status & Married & $98.9 \%$ & $\mathrm{NA}$ \\
& Separated, Divorced, Widowed & & \\
& & $77.7 \%$ & $78.8 \%$ \\
Race/Ethnicity & White & $13.4 \%$ & $\mathrm{NA}$ \\
& Black & & \\
& Asian & $6.4 \%$ & $2.1 \% *$ \\
& Native American & $1.9 \%$ & $5.2 \% *$ \\
& Hispanic & $2.6 \%$ & $1.5 \%$ \\
& & $1.9 \%$ & $0.0 \% *$ \\
& Born in the U.S. & $84.7 \%$ & $91.2 \% *$ \\
& U.S. Citizen & $14.7 \%$ & $\mathrm{NA}$ \\
& & $54.1 \%$ & $56.5 \%$ \\
& Less than High School & & \\
& High School Diploma & $32.5 \%$ & $48.7 \% *$ \\
& Some College & $30.6 \%$ & $33.2 \%$ \\
& Vocational or Technical Degree & $19.1 \%$ & $11.9 \% *$ \\
& College Degree or Higher & $12.1 \%$ & $4.7 \% *$ \\
& & $3.2 \%$ & $1.5 \%$ \\
\hline & & &
\end{tabular}

$\mathrm{NA}=$ not asked in the survey instrument

$*=$ difference is statistically significant in a $10 \%$ test

The differences are visible in the data on race/ethnicity and employment status. The drivers are overwhelmingly Hispanic - roughly $85 \%$ in 2004 and 91\% in 2006. While California is home to a large concentration of Hispanics (47.3\% in LA County and $35.9 \%$ in California versus $14.9 \%$ for the U.S.; U.S. Census), this level of concentration is unusual. Many of these drivers were born outside of the U.S. ( $85.3 \%$ in the 2004 survey) and slightly over half are U.S. citizens. There is no data on how many are working at the ports legally, but there is concern that the implementation of the Transportation Worker Identification Credential at the ports will result in a shock to the labor supply of roughly $15 \%$ (Husing et al. 2007).

The demographics depict a labor force dominated by immigrants with relatively low levels of education. While there is no metric on the drivers' English language skills, the surveys were self- 
administered and drivers could request English or Spanish versions. In both surveys approximately $80 \%$ of drivers requested Spanish versions, which might be a proxy measurement of English skills and, thus, the ability of workers to get another job. These statistics do suggest that port drayage is a career chosen by immigrant workers with relatively low levels of education who may have limited alternative job possibilities.

\section{DEREGULATION, CONTAINERIZATION, AND THE USE OF OWNER OPERATORS IN PORT DRAYAGE}

Just as striking as the prevalence of immigrant labor in the market is the reliance on self-employed drivers (owner operators). This resulted from regulatory changes in motor carriage in the late 1970s, drayage firms' relative lack of market power in the supply chain, and the changes in transportation resulting from containerization.

For ocean transportation the advent of containerization transformed the industry, moving a significant portion of freight from "break bulk" handled by gangs of longshore workers who were involved in considerable manual labor (illustrated in the film "On the Waterfront") to containerized freight moved by longshoremen using capital-intensive techniques. The standardized nature of containers means that a container can be placed directly on a train or a truck chassis and moved from the port without handling the container's contents. In concert with land scarcity and labor rules at the ports, this has resulted in the majority of goods handling activities relocating to the hinterlands from warehouses that were previously port adjacent.

Economic deregulation of interstate trucking, which began administratively in the 1970s and culminated in the Motor Carrier Act of 1980, led to significant industry changes. During regulation entry was blocked and rates were set through rate bureaus; after deregulation free entry led to considerable entry and exit in the industry, with exit by many large, incumbent truckload firms and entry of smaller, non-union firms. Not surprisingly the erosion of above average rates of return in the competitive truckload segment of the industry resulted in wages falling considerably, as the union's power was reduced. While the International Brotherhood of Teamsters retreated to less competitive segments of trucking (such as package express and less-than-truckload operations), the union density declined in truckload service (Hirsch and Macpherson 1997).

The Teamsters are currently focused on a campaign to reorganize the port drayage drivers in Southern California, under the rationale that these jobs were under union contract before deregulation. They have been hampered in their efforts due to the inability of owner operators to legally engage in collective bargaining (Wyckoff and Maister 1975). With support from both the Teamsters and various community groups, there is considerable pressure to transform the port drayage jobs from owner operator to employee, which would make it easier to organize the drivers.

While the increase in containerization, deregulation of trucking and increased U.S.-Asia trade all help explain the increased demand for trucking labor, they do not explain the heavy reliance on independent contractor labor. The latter can be explained by the drive to reduce costs by port drayage companies, in large part due to the ultra-competitive nature of the market.

The dray portion of the movement of freight from overseas is a relatively small portion of the total transportation cost and an insignificant portion of the freight value (Leachman 2008). While this would seem to suggest that drayage firms could raise rates without major impact, there is a clear imbalance of power in the supply chain. Shippers typically contract a "door to door" rate with ocean carriers that includes all transportation from origin to destination, including the dray. The number of ocean carriers has decreased due to consolidation in the industry and the development of "alliances" among the remaining carriers. In the U.S. ocean carriers are exempt from antitrust provisions and regularly conduct talks regarding rates. In contrast with the limited number of terminal operators and ocean carriers, there are approximately 16,500 owner operators operating at the ports of Long Beach and Los Angeles who contract with one of roughly 600 drayage firms. This extremely competitive market for drayage firms makes it logical to contract with owner operators to avoid the direct outlay 
on capital, fuel and insurance, and instead pay a rate for the drivers based on a percent of revenue from the load.

The labor supply of owner operator port drivers for relatively low pay is likely the result of a few main factors: truck driving being an easy occupation to enter, few language skills are required and the truck investment will yield returns to the driver once the truck has been paid off. In short, it is an entrepreneurial decision for these workers who would not otherwise have the opportunity to own their own business. Those who would classify these truck drivers as employees who pay for their own capital and operating expenses question the notion that the drivers are actually selfemployed, as few drivers operate under their own authority (Hamelin 1999).

\section{WAGES AND WORKING CONDITIONS OF PORT DRAYAGE DRIVERS}

\section{Hours of Port Drayage Drivers}

Regardless of their segment of the trucking industry, truck drivers typically work more than 40 hours per week. Exempted from the overtime provisions of the Fair Labor Standards Act, drivers' hours are governed by federal Hours of Service Regulations (HOS), which limit drivers to 60 hours of work in seven days and 14 hours of driving and non-driving work time in a 24-hour period. Though the 34-hour restart provision of HOS regulations increases the number of potential hours per week above 60 , this is not an issue for drayage drivers, as the ports have limited days and hours of operation. Table 2 presents descriptive statistics on days and hours worked. Drivers were asked for total hours worked, which included driving and non-driving work time. Non-driving work time would include as activities like waiting for a load in a terminal, waiting to be unloaded or completing paperwork.

Table 2: Owner Operator Hours Worked

\begin{tabular}{l|cc|cc}
\hline & \multicolumn{2}{|c|}{ 2004 } & \multicolumn{2}{c}{ 2006 } \\
\hline & Mean & Median & Mean & Median \\
\hline Days Per Week & 5 & 5 & 5.3 & 5 \\
Hours per day & 11.5 & 11 & 11.2 & 11 \\
Hours per week & NA & NA & 57.18 & 60 \\
\hline
\end{tabular}

The increase in the mean days worked from 2004 to 2006 is likely due to a change in operations at the Port terminals in 2005. Terminals open earlier, close later and now offer limited gate hours on Saturdays. This was part of a program, PierPASS, intended to relieve road congestion by moving traffic to off-peak hours and assessing a fee (now \$50) on peak moves. Peak hours are defined as 3 a m. to 6 p.m. on weekdays and off-peak as after $6 \mathrm{p} \mathrm{m}$. on weekdays and anytime on Saturday.

An unintended consequence of this is that drivers were able to drive more hours. In the 2004 survey, only $7 \%$ of drivers reported driving 14 hours or more and this increased to $10 \%$ in 2006 (this difference is not statistically significant). In 2006 drivers were also asked about hours worked in the last week. The mean was 57.2, and the median was 60 hours, as was the $75^{\text {th }}$ percentile. Twenty percent of drivers report driving more hours than the weekly legal limit.

Some of the violations of weekly hours limits appear to be attributable to the PierPASS program. The 2006 survey asked drivers specifically about whether they typically drove peak or off-peak and their opinions regarding PierPASS. Drivers who report primarily driving off-peak $(23.7 \%$ of the sample) reported a mean of 11.87 hours per day of driving and non-driving time, significantly higher than 11.3 hours per day averaged by the drivers who report primarily driving during peak hours. Though the difference in daily hours is statistically significant in a $10 \%$ test, the difference in hours per week is not statistically significant. 
Drivers were asked two questions specifically regarding PierPASS:

1. Are you earning more income under extended gate hours?

2. Are you working more hours under extended gate hours?

The majority of drivers reported not earning more income under the PierPASS program (53.61\% versus $46.39 \%$, a statistically significant difference in a 5\% test), and a majority reported working more hours (62.03\% versus $37.97 \%$, also statistically significant at less than 5\%). Table 3 presents a matrix of the joint probabilities of the answers to these two questions. While it may seem counterintuitive that a program designed to improve traffic flow could actually increase the hours of work, there appear to be three factors at play. First, trucking firms were more interested in dispatching drivers during off-peak hours to avoid the peak fee, which shippers were loath to pay. Second, drivers had an opportunity to drive more hours due to the terminals being open longer (which was not possible before Pier Pass). Third, PierPass actually resulted in more congestion inside the terminals since there was a reduced longshore staff working the extended hours (Hanson 2009).

Table 3: Owner Operator Drivers' Opinions on PierPASS

\begin{tabular}{l|c|c}
\hline & More Work & Not More Work \\
\hline More Income & $36.8 \%$ & $11.4 \%$ \\
Not More Income & $25.4 \%$ & $26.5 \%$ \\
\hline
\end{tabular}

\section{Earnings of Port Drayage Drivers}

While hours of work are relatively easy to measure, it is more challenging to measure the pay of drivers with precision. The bulk of port drayage drivers are paid by the trip, with the distance of the trip the major determinant of the pay rate. There are four common destinations for drays: near-dock rail yards (a rail yard operated by Union Pacific located within the Port of Long Beach), downtown rail yards (located in downtown L.A., about 20 miles away), warehouses in Los Angeles or Orange counties (typically about a 20-30 mile drive), and warehouses and distribution centers in the "Inland Empire" (Riverside and San Bernardino counties, typically a 50-75 mile drive).

Rather than focusing on pay per hour or mile, we focused on annual earnings, which seemed sensible, as the sample is limited to full-time truck drivers. Descriptive statistics on gross revenue for owner operator drivers are presented in Table 4 (figures are in 2006 dollars).

Table 4: Annual Gross Earnings for Owner Operators (in 2006 dollars)

\begin{tabular}{l|c|c}
\hline & 2004 & 2006 \\
\hline Mean & $\$ 58,551$ & $\$ 79,806$ \\
$25^{\text {th }}$ percentile & $\$ 38,325$ & $\$ 60,000$ \\
$50^{\text {th }}$ percentile & $\$ 60,225$ & $\$ 75,000$ \\
$75^{\text {th }}$ percentile & $\$ 71,175$ & $\$ 90,000$ \\
\hline
\end{tabular}

While these revenue data appear to indicate a substantial earnings increase, it is important to note that the expenses for drivers (especially fuel) increased over this period. To adjust for this, earnings are reported "net" of truck expenses and compared to the earnings of the employee drivers in the data sets. These results are presented in Table 5 (in 2006 dollars). 
Table 5: Owner Operator Net and Employee Driver Earnings, 2006 dollars

\begin{tabular}{|c|c|c|c|c|}
\hline & \multicolumn{2}{|c|}{2004} & \multicolumn{2}{|c|}{2006} \\
\hline & OO Net & Employees & OO Net & Employees \\
\hline Mean & $\$ 38,537$ & $\$ 44,179$ & $\$ 34,749$ & $\$ 44,432$ \\
\hline $25^{\text {th }}$ percentile & $\$ 18,615$ & $\$ 32,850$ & $\$ 16,673$ & $\$ 30,000$ \\
\hline $50^{\text {th }}$ percentile & $\$ 27,375$ & $\$ 43,800$ & $\$ 32,543$ & $\$ 45,000$ \\
\hline $75^{\text {th }}$ percentile & $\$ 43,800$ & $\$ 54,750$ & $\$ 45,417$ & $\$ 60,000$ \\
\hline
\end{tabular}

In 2004 drivers were asked for both their gross and net earnings, after subtracting all truckrelated expenses. The point might certainly be made that drivers may have a tendency to report their net earnings as they would report them on their income taxes, which would not capture the "true" net if drivers misreport expenses on their taxes.

In 2006 we asked drivers for specific expenses involved in their operations and used this information to calculate the net. This might also be problematic, since drivers might understate the "value" of repairs they do themselves or overlook the time they spent working on their business (such as doing paperwork). Nevertheless, the resulting nets appear consistent with one another, so they are likely the closest approximation one can get without a detailed analysis of all time and costs involved in an owner operator's business operation. They are also consistent with the results of Husing et al. (2007).

Two facts are clear. First, employee drivers earn more than owner operators for their labor. Second, while there are drivers who earn considerable amounts of money at the upper ends of the earnings distribution, a considerable amount of owner operators' revenues are spent on operating expenses, effectively lowering the amount they earn for their labor, assuming the labor payments are the residual after truck expenses are paid. These expenses were the focus of the 2006 survey. Table 6 presents the major truck expenses, as well as their means and medians for the "big ticket" expenses, excluding the truck itself.

Table 6: Owner Operator Truck-Related Expenses, 2006

\begin{tabular}{lcc}
\hline Expense Type & Median & Mean \\
\hline Diesel & $\$ 450 /$ week & $\$ 500 /$ week \\
Insurance & $\$ 600 /$ month & $\$ 606 /$ month \\
Maintenance & $\$ 5000 /$ year & $\$ 7044 /$ year \\
\hline
\end{tabular}

The expenses on maintenance vary considerably (as is evident from the difference between the mean and the median), while the expenditures on diesel and insurance have less variation. The payment on the truck itself varies considerably, mainly due to the fact that most of the owner operators surveyed had paid off their truck (62.5\%). Among those still making payments on their trucks, the average monthly payment is $\$ 892$.

\section{Determinants of Net Earnings and Owner Operator Margins}

Typically, an analysis of wages would involve the estimation of a human capital wage equation to isolate the determinants of the wage. Using the 2004 data, two models can be estimated, assuming a parsimonious model due to the small sample size. One model has the driver's net annual income (income that has been adjusted for truck-related expenses) as the dependent variable, and the second model has the hourly wage (defined as net annual income divided by annual hours) as the dependent variable. Explanatory variables for both models include firm size, experience (years as a truck 
driver), tenure (years with the current firm) and education. Controls are also included for race, ethnicity and whether the respondent was born in the U.S.

The results from this model are presented in Appendix A and suggest that such a model does little to capture the major determinants of net earnings for these drivers. The adjusted R-square is 0.15 in the annual earnings model and 0.09 in the hourly earnings model, and few variables are statistically significant. The coefficient on the born in the U.S. dummy is large $(10,686)$ and significant $(\mathrm{p}=0.08)$ in the annual earnings estimation, which suggests that language skills may play a role in improving earnings among these drivers.

Most notable is that there are no returns to tenure, experience or education, a result consistent with Belman and Monaco's 2001 study of long-haul truckers. Much like over-the-road drivers, port drivers in the sample have relatively low levels of tenure, and there is little reason to believe that firms would reward drivers for firm attachment when labor is easily substituted, considering there are few firm-specific skills in port drayage.

If a human capital regression model does not yield significant information about the determinants of net earnings, what is the primary determinant? Not surprisingly, it is the truck-related expenses a driver incurs. Using data from the 2006 survey, we calculate the ratio of net to gross income, presented in Figure 1.

The mean ratio of net to gross earnings across owner operators is 0.466 with a median of 0.487 . If the sample is split by whether drivers have paid off their trucks, the ratio is 0.526 among those drivers who own their trucks and 0.397 among those who do not. This difference is statistically significant at the $1 \%$ level. This is expected, given that trucks are a major capital expense. Since drivers must finance their own trucks, they do not purchase trucks from recent model years, as new diesel trucks cost $\$ 100,000$ or more. Figure 2 presents the distribution of truck ages in the 2006 sample, and Figure 3 presents the distribution of truck ages at purchase.

Figure 1: Owner Operators' Ratio of Net Earnings to Gross Earnings, 2006

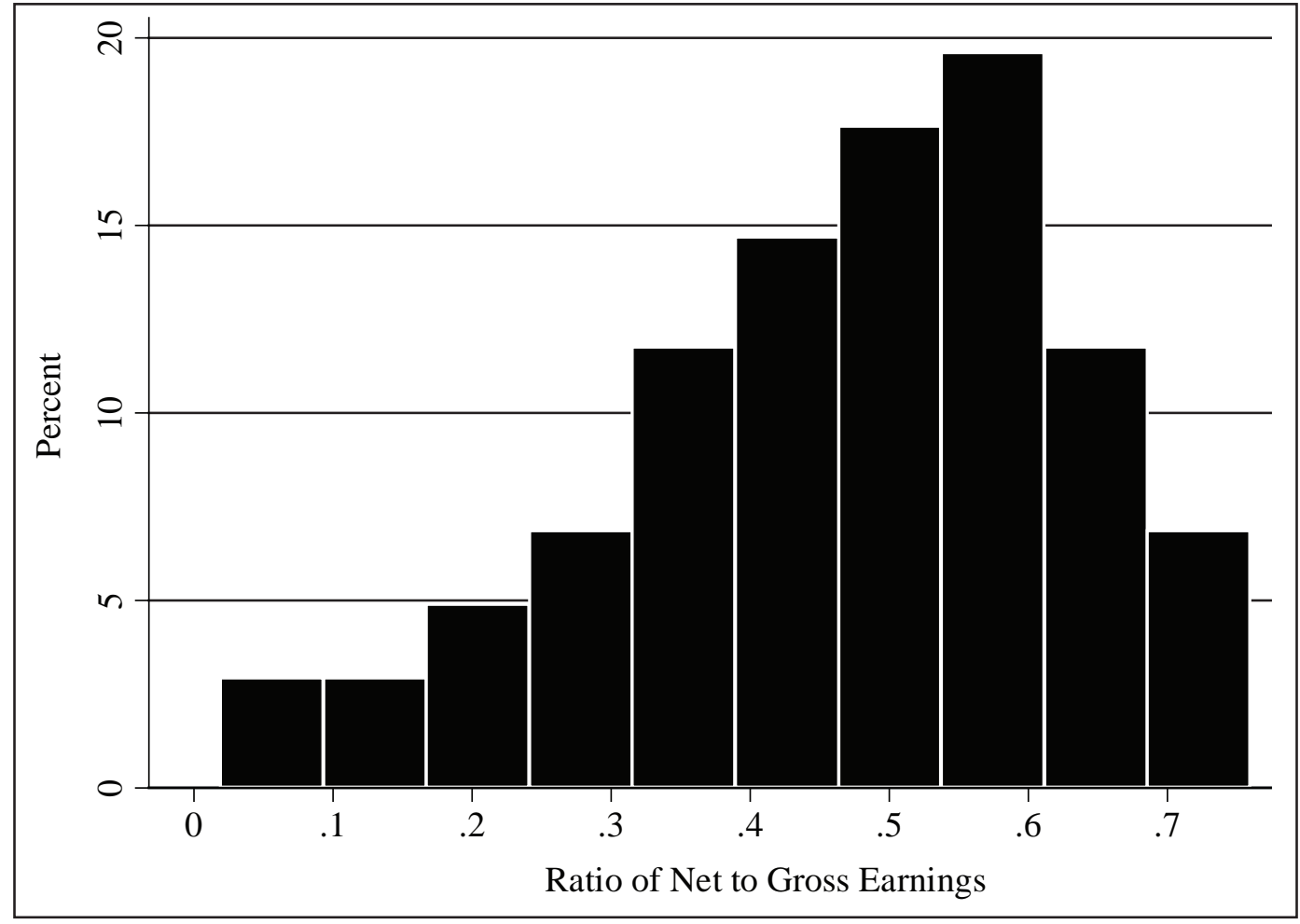


Figure 2: Distribution of Truck Model Year, 2006

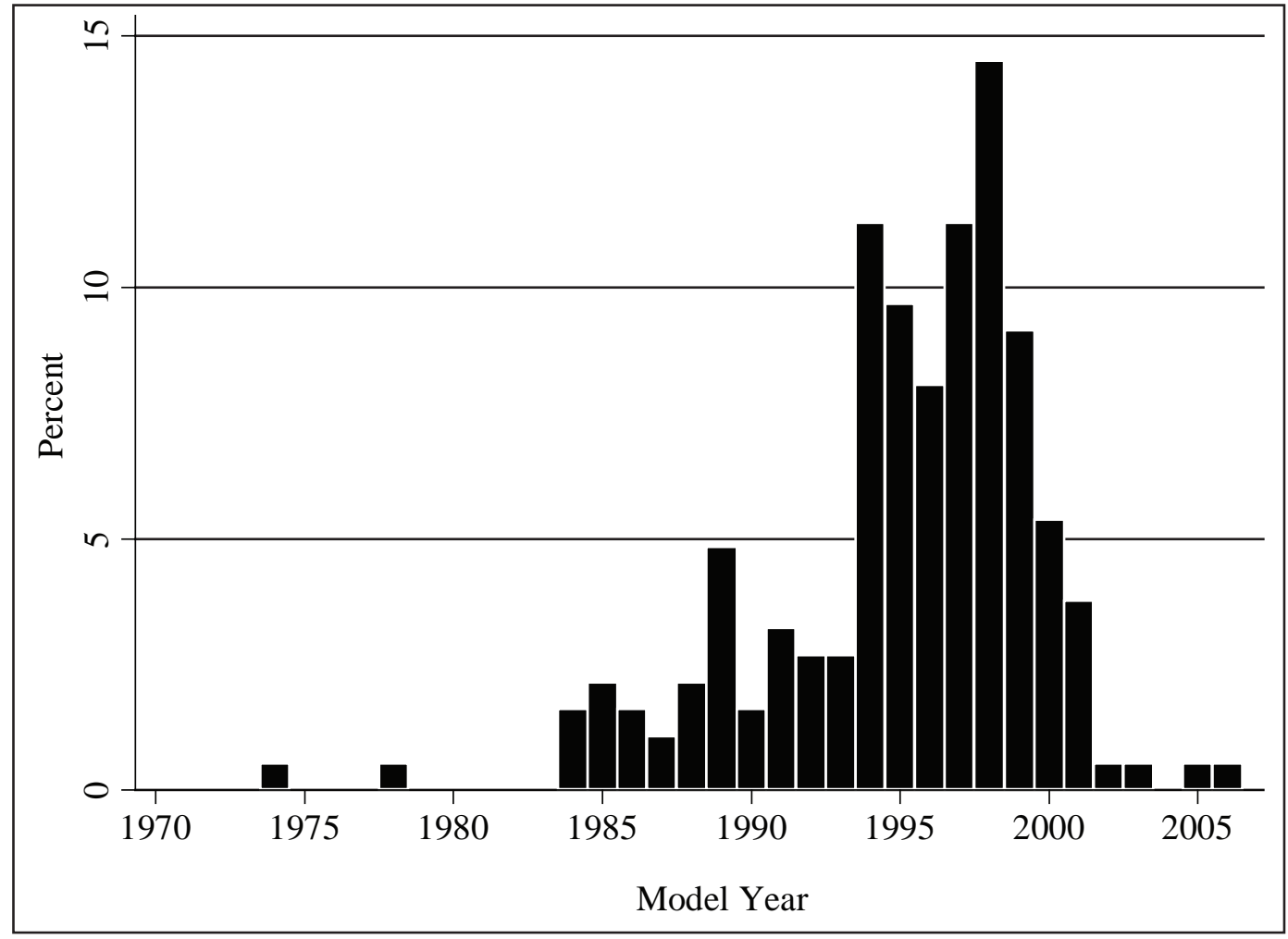

Figure 3: Distribution of Truck Age at Purchase, 2006

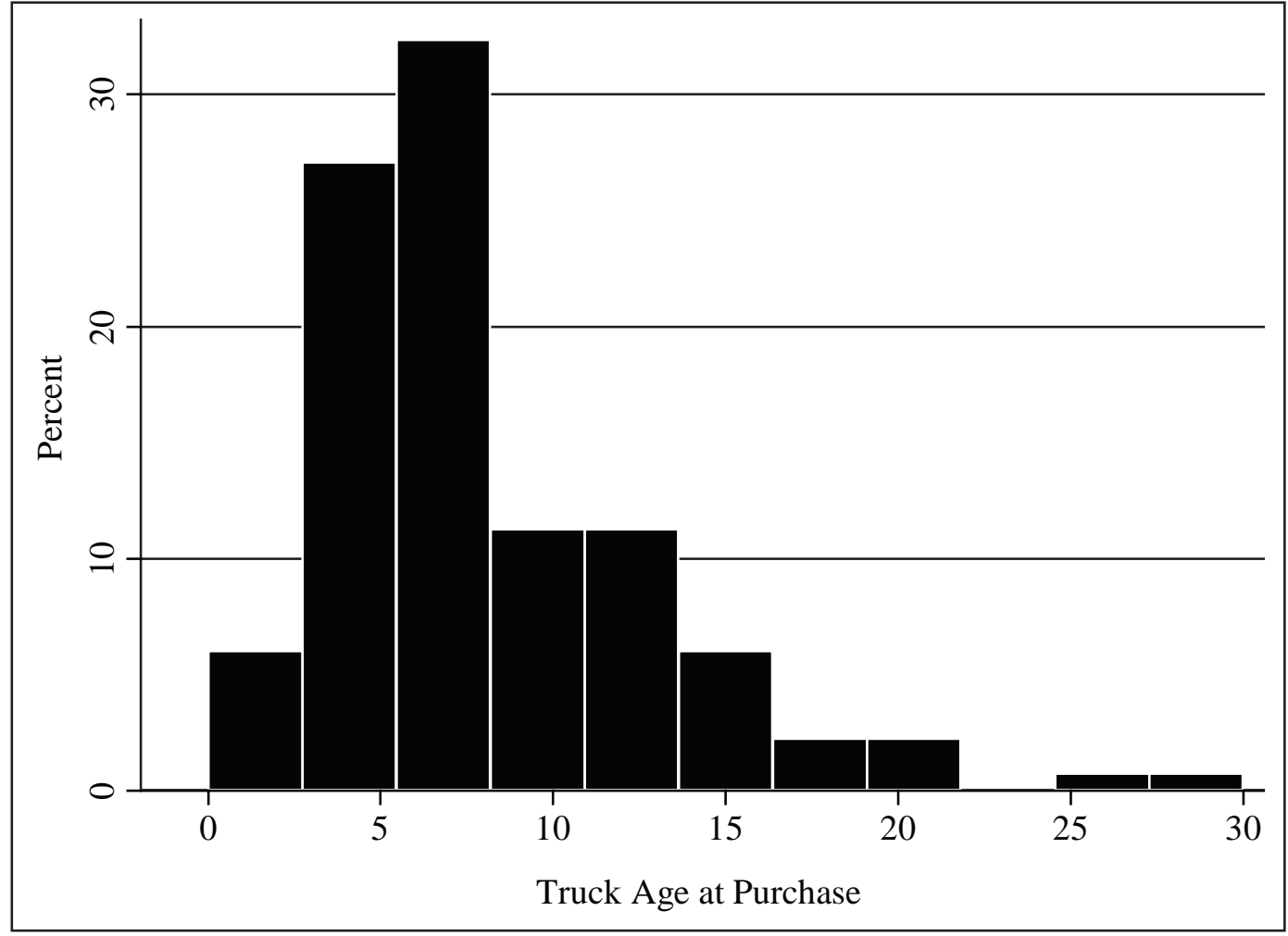


Most trucks are model years 1994-1998. The oldest model year in the sample was 1974 and the newest is 2006. The mean is 1995. The mean age of the truck at the time of purchase is seven years, with roughly a quarter of trucks purchased at nine or more years of age.

To understand the lifecycle of a "typical" diesel truck, it is important to note that large, national carriers typically replace one-third of their trucks every year (long haul trucks are driven in excess of 100,000 miles per year). Thus, there are many three-year-old trucks on the used truck market, which may then be purchased by a smaller local or regional carrier, who keeps the truck for another 3-4 years and then sells it. By the time these trucks are purchased in the drayage market, they are " 3 rd generation" trucks. The use of older trucks generates substantial pollution problems. According to the Port of Long Beach Air Emissions Inventory, trucks servicing the Port generate $24 \%$ of all port-related diesel particulate matter, $33.8 \%$ of all port-related NOx, and $56.9 \%$ of all port-related carbon monoxide (Port of Long Beach 2007). As previously stated, the ports of Long Beach and Los Angeles are implementing new programs to replace older model trucks with trucks that meet 2007 EPA standards (either new trucks or retrofitted older models). It is important to note that the emissions problems are not simply due to the age of trucks, but the amount of time trucks spend idling at the terminals. This latter problem will not be directly addressed by the environmental regulations, but the overall pollution level will be improved due to newer, less polluting trucks without necessarily making the system more efficient.

\section{A MODEL OF WAITING TIME}

A key issue facing drivers in port operations is the amount of time they spend waiting at port terminals. Since the vast majority of the drivers are paid by the trip, their income is decreased as waiting time increases. The increased volume of trade coming into the LA-area ports has brought longer lines at terminals. In order to address health concerns related to truck idling, California Assembly Bill 2650 (passed in 2002 and enacted in 2003) imposed fines on terminal operators if trucks idle outside their gates for more than 30 minutes. Though this law brought attention to the problems of truck congestion at the ports, the fact that terminals are not fined if they maintained appointment systems or extended gate hours has led to general consensus that the law has had little effect on the amount of time trucks spend waiting at the ports.

Queues at terminals occur for a variety of reasons. Unlike a taxi queuing model at an airport, the terminal cannot simply give the next available container that needs to be delivered to the driver as he arrives at the terminal. Drivers need to be matched with their particular load. Ideally terminal operators would know when a driver was arriving for a specific load, mount it on a chassis and have it waiting for the driver when he arrives. As more container terminals stack containers to increase their capacity, they assign less land space to "staging areas." Thus, a driver might arrive to pick up a container and have to wait a significant period of time for the container to be located in the stacks and placed on a chassis.

Determinants of waiting time should therefore include factors that increase the likelihood that the container is made available as quickly as possible. Clearly, most of these are either immeasurable or would require detailed data from terminal operators that they are unlikely to provide. Rather, factors in the employment relationship or characteristics of drivers that might affect this likelihood can be identified. Drayage companies who employ drivers (rather than contract with owner operators) have greater incentive to use their capital efficiently and therefore dispatch employee drivers to more efficient terminals or for loads that they know are ready to be picked up.

Larger drayage firms might also have an advantage either through better coordination with terminals, only calling at the most efficient terminals, or by the flexibility to reassign drivers to different loads if a particular container is not ready to be picked up.

More experienced drivers may have "institutional" knowledge that allows them to reduce their waiting time, knowledge perhaps manifested by contracting with drayage companies known to be efficient, refusing loads from less efficient terminals, or developing relationships with the workers 
at particular terminals. Finally, it may be the case that drivers who lack language skills are more likely to be delayed at the terminals. Evidence from the wage estimation shows that drivers born in the U.S. tend to earn more (net of trucking expenses). This may simply be the result of increased productivity (less time spent waiting).

On average port drivers in the 2004 survey report $48 \%$ of their trip time is spent waiting to get in and out of the port. Among owner operators the mean is $50.2 \%$, significantly higher than the $40.7 \%$ ratio of employee drivers (significant at the $1 \%$ level). The ratio of waiting time is modeled as a function of tenure, experience, whether or not the driver is an owner operator and whether the driver was born in the U.S. The results are presented in Table 7. As expected from the descriptive statistics, the sign on the owner operator dummy variable is positive and significant. Owner operators experience more waiting time than employee drivers, all else being equal, which supports the hypothesis that firms that employ drivers will use employee drivers' time more efficiently, since the firms directly bear the cost of inefficient use of employee drivers. As firms do not directly experience additional costs from owner operators having longer waiting times, they are more likely to contract with owner operators for loads that involve longer periods of waiting time.

Table 7: Waiting Time Estimation

\begin{tabular}{lcc}
\hline Variable & Coefficient & t-statistic \\
\hline Owner Operator & $0.0792 * *$ & 2.08 \\
Experience & $-0.0057 * *$ & -2.28 \\
Tenure & -0.0019 & -0.38 \\
Firm size 25-99 & -0.0527 & -1.36 \\
Firm size 100-249 & -0.0109 & -0.18 \\
Firm size 250 plus & $-0.1575 * * *$ & -2.77 \\
Born in U.S. & $-0.1243 * * *$ & -2.72 \\
Constant & 0.5500 & 11.70 \\
& & \\
n & 144 & \\
\hline
\end{tabular}

* significant at $10 \%$ level

** significant at $5 \%$ level

$* * *$ significant at $1 \%$ level

There is a negative relationship between experience and waiting time, providing support for the hypothesis that drivers who have been in the occupation longer find ways to circumvent inefficiencies. Drivers at the largest firms (250 or more drivers) have less waiting time, supporting the hypothesis that these firms may use labor more efficiently. Finally, there is evidence that those born in the U.S. have less waiting time that those born outside of the U.S. This suggests that the lower wages earned by those born outside of the U.S. may be somewhat attributable to language skills.

\section{CONCLUSION}

Port drayage drivers at the ports of Los Angeles and Long Beach are critical to goods movement within Southern California and provide a key link to trade between the region and the rest of the country. Using two data sets, this paper describes the earnings and work of these drivers, most of whom are owner-operators and many who are not native to the United States.

These self-employed drivers bear the risk of fluctuations in diesel prices, insurance costs and capital expenditure, allowing drayage companies to operate with significantly lower fixed costs. The 
drivers work long hours (on average 11.2 hours per day) and spend nearly half of their time involved in non-driving work (such as waiting at the ports). Owner operator drayage net earnings in 2006 averaged approximately $\$ 35,000$, substantially lower than the $\$ 44,432$ average of employee dray drivers. A model of net annual earnings for port drivers finds no returns on education, experience or tenure. The key determinant of net pay appears to be truck-related expenses. Those who have fully paid for their trucks earn substantially more than both owner operators still making truck payments and employee dray drivers. This gives an incentive for drivers to buy older, less expensive trucks (most trucks are model years 1994-1998) that generate a great deal of pollution.

While new regulations planned at the major California ports will phase out the oldest trucks, only the Port of Los Angeles has finalized plans to require that all drivers have employee rather than owner operator status. In theory, this should lead to more efficient truck operations within the terminals, where we find that owner operators, those from smaller firms and those born outside the U.S. have significantly longer waiting times than employee drivers, drivers from the largest companies and drivers born in the U.S. Though the American Trucking Association has a lawsuit pending that challenges the employee driver requirement, the mayors of Oakland, New York and Newark have supported programs that would both strengthen environmental regulations and support plans to unionize drivers at the ports (White 2009).

\section{Acknowledgements}

The author would like to acknowledge the support of METRANS in providing funding for the 2004 and 2006 Driver Surveys.

\section{Endnotes}

1. While it is customary to ask respondents separately about race and ethnicity (as does the CPS), this caused some confusion among the respondents in 2004, so in 2006 we asked about race and ethnicity in the same question. The 2004 responses have been adjusted to reflect this, thus all respondents reporting "White" are non-Hispanic Whites (and the same holds for the other racial categories).

\section{References}

Belman, Dale L. and Kristen A. Monaco. "The Effects of Deregulation, De-unionization, Technology, and Human Capital on the Work and Work Lives of Truck Drivers." Industrial and Labor Relations Review 54 (2), (2001): 502-24.

Belman, Dale L., Kristen A. Monaco, and Taggert J. Brooks. Sailors of the Concrete Sea: A Portrait of Truck Drivers Work and Lives. Michigan State University Press, Lansing, MI, 2005.

Belzer, Michael H. Sweatshops on Wheels: Winners and Losers in Trucking Deregulation. Oxford University Press, New York, NY, 2000.

Hamelin, Patrick. "Social Aspects of Road Transport Drivers' Working Hours.” Social Aspects of Road Transport. Organization for Economic Cooperation and Development, Paris and Washington, D.C. (1999): 67-88.

Hanson, Kristopher. On the Waterfront. Long Beach Press Telegram, on-line edition, 10/12/2009.

Hirsch, B. and D. MacPherson. "Earnings and Employment in Trucking: Deregulating a Naturally Competitive Industry." James Peoples ed. Regulatory Reform and Labor Markets. Norwell, MA: Kluwer Academic Publishers (1997): 61-112. 
Husing, John E., Thomas E. Brightbill and Peter A. Crosby. "San Pedro Bay Ports Clean Air Action Plan Economic Analysis: Proposed Clean Truck Program.” Report available at http://www. portoflosangeles.org/CAAP/CTP_Full_Report_Sept72007.pdf, 2007.

Journal of Commerce. "The JoC's Top 50 World Container Ports.” Journal of Commerce, (July 28, 2008): 28-36.

Leachman, Robert C. "Port and Modal Allocation of Waterborne Containerized Imports from Asia to the United States." Transportation Research, Part E 44 (2), (2008): 313-331.

PierPASS Inc. "Q\&A on PierPASS Inc. and the Off-Peak Program." Available at: http://www. pierpass.org/files/offpeak_program/OffPeak_QA_7_22_08.pdf.

Port of Long Beach. “2005 Air Emissions Inventory.” Report available at http://polb.com/civica/ filebank/blobdload.asp?BlobID=4412 2007.

U.S. Census Bureau. "State and County Quick Facts.” http://www.quickfacts.census.gov.

White, Ronald D. “L.A., Long Beach Ports' Feud Resurfaces.” Los Angeles Times, on-line edition, $11 / 28 / 2009$.

Wyckoff, D. Daryl and David H. Maister. Owner Operator: Independent Trucker. Lexington Books, Lexington, MA, 1975.

Kristen Monaco is a professor of economics and director of the graduate program in global logistics at California State University Long Beach. Her research centers on the impact of market structure on labor markets, with a focus on the trucking industry. 
Wages and Working Conditions

APPENDIX A: Wage Estimation

\begin{tabular}{l|c|c|c|c}
\hline & \multicolumn{2}{|c|}{ Annual Earning Estimation } & \multicolumn{2}{c}{ Hourly Earnings Estimation } \\
\hline Variable & Coefficient & t-statistic & Coefficient & t-statistic \\
\hline Experience (in years) & 41.438 & 0.15 & -0.008 & -0.08 \\
Tenure (in months) & 475.283 & 0.78 & 0.077 & 0.33 \\
Some College & -997.636 & -0.23 & -0.150 & -0.10 \\
Vocational/ Associate's Degree & -2855.599 & -0.53 & -1.142 & -0.56 \\
College & -6946.763 & -0.58 & -2.656 & -0.59 \\
Firm size 25-99 & -2334.811 & -0.56 & -1.079 & -0.67 \\
Firm size 100-249 & $-9991.611 *$ & -1.70 & $-4.053 *$ & -1.78 \\
Firm size 250 plus & 6349.509 & 0.75 & 4.361 & 1.30 \\
Black & -12314.75 & -0.84 & -0.342 & -0.06 \\
Asian & -2036.832 & -0.13 & 2.988 & 0.53 \\
Hispanic & -5872.765 & -0.80 & 2.059 & 0.73 \\
Born in the U.S. & $10685.61 *$ & 1.79 & 3.526 & 1.59 \\
Constant & 41928.87 & 3.91 & 10.454 & 3.02 \\
n & 123 & & 123 & \\
R-squared & 0.15 & & 0.09 & \\
\hline
\end{tabular}

*significant at $10 \%$ level 